\title{
A systematic review on harmful alcohol use among civilian populations affected by armed conflict in low- and middle-income countries
}

Revision 4 (January 2017)

\section{ABSTRACT}

Background: There are currently over 55 million refugees and internally displaced persons due to armed conflict. In addition, there around 150 million more conflictaffected residents who remain in their home communities. Armed conflict poses a number of potential risks for harmful alcohol use.

Objective: The objective of the study was to systematically examine evidence on harmful alcohol use among conflict-affected populations in low- and middle-income countries.

Methods: A systematic review methodology was used following PRISMA guidelines. Quantitative studies were selected with outcomes relating to harmful alcohol use among conflict-affected populations in low- and middle-income countries. Seven bibliographic databases and a range of grey literature sources were searched. Descriptive analysis was applied and a quality assessment conducted using the Newcastle-Ottawa Quality Assessment Scale.

Results: The search yielded 10037 references of which 22 studies met inclusion criteria. Twenty-one of the studies used a cross-sectional design, and 1 used a case 
series design. Evidence on risk-factors for harmful alcohol use was weak overall. Factors associated with harmful alcohol use were male gender, older age, cumulative trauma event exposure, and depression. There were no studies on the effectiveness of interventions for harmful alcohol use. The strength of evidence was also limited by the generally moderate quality of the studies.

Conclusions: Substantially more evidence is required to understand the scale of conflict-associated harmful alcohol use, key risk factors, association of alcohol use with physical and mental disorders, and effectiveness of interventions to address harmful alcohol use in conflict-affected populations. 


\section{A systematic review on harmful alcohol use among civilian populations affected by armed conflict in low- and middle-income countries}

\section{BACKGROUND}

There are currently over 55 million individuals forcibly displaced worldwide as a result of conflict, persecution, violence, or human rights violations. This figure includes over 38 million internally displaced persons (IDPs) who remain within the borders of their countries and 18 million refugees living in other countries.(IDMC, 2015; UNHCR, 2014) In addition to refugees and IDPs, there are approximately 150 million conflict-affected residents (CARs) who remain living in their home areas currently affected by conflict (rather than been forcibly displaced as refugees or IDPs).(CRED, 2013) The vast majority of conflict-affected populations (i.e. IDPs, refugees, and CARs) are concentrated in low- and middle-income countries (LMICs).(IDMC, 2015; UNHCR, 2014)

Harmful alcohol imposes a significant health burden globally, acting as a risk factor for a wide spectrum of physical and mental illnesses, as well as causing social and economic burdens.(Rehm, Mathers, Popova, Thavorncharoensap,

Teerawattananon, \& Patra, 2009; WHO, 2011; WHO, 2015b) Armed conflict poses a number of potential specific risks for harmful alcohol use. It exposes populations to violent and traumatic events known to increase the incidence and severity of mental disorders such as post-traumatic disorder (PTSD) and depression.(de Jong, Komproe, \& Van Ommeren, 2003; Levy \& Sidel, 2009; Steel, Chey, Silove, Marnane, Bryant, \& van Ommeren, 2009) Exposure to traumatic events and presence of major 
depression diagnosis are known to be associated with harmful alcohol use,(Boden \& Fergusson, 2011; G. B. D. Risk Factors Collaborators, 2015) with alcohol potentially contributing to mental disorders but also mental disorders also potentially leading to harmful alcohol use. Studies of military personnel (in high-income countries) have highlighted a strong association between trauma exposure, mental disorders such as PTSD and harmful alcohol use.(Jones \& Fear, 2011; Kehle, Ferrier-Auerbach, Meis, Arbisi, Erbes, \& Polusny, 2012; Kline, Weiner, Ciccone, Interian, St Hill, \& Losonczy, 2014)

In addition, the hardships experienced in conflict and post-conflict settings including limited access to health care, poor living conditions, loss of family and friends, and fragmented social support, may contribute to harmful alcohol use.(Ezard, 2012; Lo, Patel, \& Roberts, 2015) Evidence from stable settings highlights the relationship between low social capital to individual high risk alcohol use,(Weitzman \& Chen, 2005) and the greater harm per unit alcohol consumed in poor populations than rich ones.(Rehm, Mathers, Popova, Thavorncharoensap, Teerawattananon, \& Patra, 2009)

Harmful alcohol use is also a known risk-factor for NCDs in stable settings (Boden \& Fergusson, 2011; G. B. D. Risk Factors Collaborators, 2015) and NCDs are a growing disease burden among conflict-affected populations.(Demaio, Jamieson, Horn, de Courten, \& Tellier, 2013) Evidence from stable settings also suggests harmful alcohol use increases risk for communicable diseases such as HIVIAIDS and tuberculosis (e.g. through risky sexual behaviour and substance misuse) and 
interruptions in their treatment.(Baliunas, Rehm, Irving, \& Shuper, 2010; Rehm, Samokhvalov, Neuman, Room, Parry, Lonnroth, Patra, Poznyak, \& Popova, 2009; Shuper, Joharchi, Irving, \& Rehm, 2009) The social impacts of harmful alcohol use may be magnified in part due to alcohol's link to gender-based and family violence which are major concerns in many conflict-affected settings.(UN, 2014; WHO, 2006) Harmful alcohol use also creates economic impacts, including health care costs.(Rehm, Mathers, Popova, Thavorncharoensap, Teerawattananon, \& Patra, 2009) In addition, post-conflict environments may also provide opportunities for national and transnational alcohol companies to expand their marketing and promotion activities, especially in situations where alcohol regulations and enforcement are weak, and such activities increase alcohol use and subsequent harm.(Bakke \& Endal, 2010; Casswell \& Thamarangsi, 2009; Roberts \& Ezard, 2015; Wallace \& Roberts, 2014).

Previous systematic reviews in 2010 and 2012 found some limited evidence on the influence of forced displacement on harmful alcohol use.(Ezard, 2012; Weaver \& Roberts, 2010) However, these systematic reviews were limited to refugees and IDPs rather than also including CARs and persons living in post-conflict situations. Furthermore, these reviews did not assess the quality of the evidence using formal metrics. Therefore, there is a need for a more up-to-date and comprehensive systematic review on harmful alcohol use among all conflict-affected populations in LMICs. 
The overall objective of this study was to systematically examine evidence on harmful alcohol use among conflict-affected populations in LMICs. The specific objectives were to examine: (1) the prevalence and patterns harmful alcohol use; (2) risk-factors associated with harmful alcohol use; (3) the association of harmful alcohol use with other harmful behaviours; and (4) to review the quality of the evidence.

\section{METHODOLOGY}

This study used a systematic review method following the Preferred Reporting Items for Systematic Reviews and Meta-Analyses (PRISMA) statement (see Online Appendix 1 for the completed PRISMA Checklist).(Moher, Liberati, Tetzlaff, Altman, \& Group, 2009)

\section{Eligibility criteria}

The main outcome of interest was harmful alcohol use, defined as excessive use that causes damage to health and often includes adverse social consequences.(WHO, 2011) This is commonly measured by instruments such as: the Alcohol Use Disorders Identification Test (AUDIT) which screens for hazardous, harmful and dependent use;(Babor TF, Higgins-Biddle JC, Saunders JB, \& Monteiro MG 2001) the CAGE questionnaire which screens for excessive drinking and dependence;(Ewing, 1984) the Mini International Neuropsychiatric Interview (MINI) which diagnoses alcohol dependence and abuse;(Sheehan, Lecrubier, Sheehan, Amorim, Janavs, Weiller, Hergueta, Baker, \& Dunbar, 1998) and the Composite International Diagnostic Interview (CIDI) which diagnoses alcohol disorder.(Robins, 
Wing, Wittchen, Helzer, Babor, Burke, Farmer, Jablenski, Pickens, Regier, \& et al., 1988) Harmful alcohol use is also measured by volume and frequency of alcohol consumed. Any alcohol use by children and adolescents (under the age of 18 years) was also considered as harmful alcohol use for this review. Alcohol use included industrially produced alcohol as well as home and illicitly produced alcohol.

The populations of interest were conflict-affected civilian populations such as IDPs, refugees and CARs remaining in their homes during active conflict, and also residents living in post-conflict countries. Internationally accepted definitions for refugees and IDPs were used.(Deng \& United Nations, 1998; UN, 1951) Armed conflict was defined as "a contested incompatibility which concerns government and/or territory where the use of armed force between two parties, of which at least one is the government of a state, results in at least 25 combatant battle-related deaths per year."(Uppsala University, 2015) There is no consensus standard for the duration of a "post-conflict" period; in the present study we defined the post-conflict interval as $\leq 10$ years following the formal cessation of the conflict.(Brown, Langer, \& Stewart, 2011; Collier \& Hoeffler, 2004)

The study focused on conflict-affected populations in low- and middle-income countries (LMICs) (The World Bank, 2015) as the vast majority live in LMICs.(IDMC, 2015; UNHCR, 2014) Furthermore, the psychological stressors experienced (e.g. insecurity and impoverishment), and the availability of support services and effective interventions, are likely to be worse in LMICs compared to high-income countries. 
Primary quantitative research studies published from January 1994 to December 2014 from published and grey literature were searched. The search started on 8 December 2015 and was completed on 15 December 2015.

\section{$\underline{\text { Information sources and search strategy }}$}

Only quantitative studies were included. Both published and grey literature were included. The bibliographic databases used to search for published literature were: EMBASE, Global Health, MEDLINE, PsycEXTRA, PsycINFO, Web of Science and Cochrane. Grey literature was searched through the following websites and humanitarian databases: World Health Organization (WHO), United Nations High Commissioner for Refugees (UNHCR), United Nations Office for the Coordination of Humanitarian Affairs (UNOCHA), Médecins Sans Frontières Field Research, ReliefWeb, and Google (first 10 pages only).

The search strategy used a series of terms related to armed conflict and forced displacement crossed with a series of terms related to alcohol. The full free text and MESH terms used for the bibliographic databases appear in Online Appendix 2.

Excluded from consideration were: qualitative studies, studies published in languages other than English or Spanish, abstract-only studies, conference abstracts, studies focusing on military personnel, and investigations conducted in high-income countries. The screening and review process is detailed in figure 1. 
Data were extracted based on the study objectives and included standard data extraction fields, plus harmful alcohol use measures/outcomes, harmful alcohol drinking prevalence, patterns of alcohol use, risk factors for harmful alcohol use, and association of harmful alcohol use with other harmful behaviours, and evaluation of study quality.

\section{Analysis and quality assessment}

Descriptive analysis was conducted, and statistical significance was assumed at $p<0.05$ when describing the results. Due to the heterogeneity of study designs and outcomes, meta-analysis was not carried out.

The quality of studies, including risk of bias in individual studies, was assessed using the Newcastle-Ottawa Scale (Online Appendix 3) which has been adapted for use with cross-sectional studies.(Herzog, Alvarez-Pasquin, Diaz, Del Barrio, Estrada, \& Gil, 2013; Wells, Shea, O'Connell, Peterson, Welch, Losos, \& Tugwell, 2014) Three broad perspectives are assessed in the scale using a star system: the selection of study groups (selection bias, sampling, non-respondents); the comparability of the groups (adjustment for confounders); and the ascertainment of exposure/outcome of interest. Each study was given a quality rating of strong, moderate or weak based on this scale ('strong'=8-10 stars; 'moderate'=5-7 stars; 'weak'=0-4 stars).

The study screening and quality assessment were conducted independently by two of the study authors (JL, PP; who had not authored any of the papers under review). 
Any differences in findings were resolved through discussion between them and a third author (BR).

\section{RESULTS}

\section{Study selection and characteristics}

10037 studies were identified through the bibliographic database search (2460 from Embase; 1061 from Global Health; 1391 from MEDLINE; 199 from PsycExtra; 1749 from PsycINFO; 3177 from Web of Science), of which 3366 were duplicates and excluded. Titles and abstracts were screened for 6671 studies and 6630 studies were excluded due to reasons such as non-English/Spanish language, published before 1994, not civilian specific, non-alcohol related or from high-income countries. Forty studies were selected for full text review, with one study excluded as full text could not be obtained.(Buljan, Vrcek, Cekic-Arambasin, Karlovic, Zoricic, \& GolikGruber, 2002). The grey literature search yielded no additional eligible papers to those already identified in the published literature search. A final 22 studies met the inclusion criteria and were included in the analysis (Figure 1).(Abu Qamar, Thabet, \& Vostanis, 2007; Akinyemi \& Owoaje, 2011; Bosnar, Stemberga, Cuculic, Zamolo, Stifter, \& Coklo, 2004; Ezard, Thiptharakun, Nosten, Rhodes, \& McGready, 2012; Fu \& Van Landingham, 2010; Harris, Levey, Borba, Gray, Carney, \& Henderson, 2012; Hewitt RamíRez, Gantiva DíAz, Vera Maldonado, Cuervo RodríGuez, Nelly Liliam, JuÁRez, \& Parada BaÑOs, 2014; Jovic-Vranes, Vranes, Marinkovic, \& Cucic, 2005; Kebede, Alem, Mitike, Enquselassie, Berhane, Abebe, Ayele, Lemma, Assefa, \& Gebremichael, 2005; Kozaric-Kovacic, Ljubin, \& Grappe, 2000; Londono, Romero, \& Casas, 2012; Luitel, Jordans, Murphy, Roberts, \& McCambridge, 2013; Maksimovic, 
Backovic, Maksimovic, \& Kocijancic, 2011; O'Donnell \& Roberts, 2015; Okello, Nakimuli-Mpungu, Musisi, Broekaert, \& Derluyn, 2013; Priebe, Bogic, Ajdukovic, Franciskovic, Galeazzi, Kucukalic, Lecic-Tosevski, Morina, Popovski, Wang, \& Schuetzwohl, 2010; Puertas, Rios, \& Valle, 2006; Roberts, Felix Ocaka, Browne, Oyok, \& Sondorp, 2011; Roberts, Murphy, Chikovani, Makhashvili, Patel, \& McKee, 2014; Saile, Ertl, Neuner, \& Catani, 2014; Saile, Neuner, Ertl, \& Catani, 2013; Sibai, Tohme, Beydoun, Kanaan, \& Sibai, 2009)

The final 22 studies were published between 2000 and 2014, and the median year of publication was 2011. Twenty studies used cross-sectional designs, including one mixed methods study for which only the quantitative findings were analysed for our review.(Ezard, Thiptharakun, Nosten, Rhodes, \& McGready, 2012) The remaining study used a case series design $(n=1)$.(Bosnar, Stemberga, Cuculic, Zamolo, Stifter, \& Coklo, 2004). The studies were from countries in Africa $(n=8)$, Asia $(n=3)$, the Middle East $(n=4)$, Europe $(n=4)$, and Latin America $(n=3)$. The study populations included IDPs $(n=5)$, refugees $(n=4)$, general populations of CARs and persons in post-conflict situations ( $n=3)$, and specific populations such as university students, adolescents, and secondary school students in conflict and post-conflict settings (Table 1).

\section{Patterns of harmful alcohol use}

The prevalence of harmful alcohol use was provided in 18 of the 22 selected studies. Harmful alcohol use was identified in eight studies by a range of instruments such as the full AUDIT or its shorter forms $(n=4)$ (Ezard, Thiptharakun, Nosten, Rhodes, \& 
McGready, 2012; Luitel, Jordans, Murphy, Roberts, \& McCambridge, 2013; Roberts, Felix Ocaka, Browne, Oyok, \& Sondorp, 2011; Roberts, Murphy, Chikovani, Makhashvili, Patel, \& McKee, 2014), CAGE questionnaire (n=2) (Hewitt RamíRez, Gantiva DÍAz, Vera Maldonado, Cuervo RodríGuez, Nelly Liliam, JuÁRez, \& Parada BaÑOs, 2014; Kozaric-Kovacic, Ljubin, \& Grappe, 2000), and the MINI $(n=2)$ (Akinyemi \& Owoaje, 2011; Priebe, Bogic, Ajdukovic, Franciskovic, Galeazzi, Kucukalic, Lecic-Tosevski, Morina, Popovski, Wang, \& Schuetzwohl, 2010). For these results, we use the term 'harmful alcohol use' as an umbrella term, and the specific terms used by these instruments are provided in Table 1.

The results on patterns of harmful alcohol use are summarised in Table 1. The highest prevalence of harmful alcohol use among adults (defined by measures such as AUDIT score>7, CAGE questionnaire or MINI positive) was with male IDPs in Croatia (60.5\%) (Kozaric-Kovacic, Ljubin, \& Grappe, 2000), and the lowest was found among female university student in Gaza Strip (0.2\%).(Abu Qamar, Thabet, \& Vostanis, 2007) Five studies provided information on harmful alcohol use related to frequency and volume of alcohol consumed.(Ezard, Thiptharakun, Nosten, Rhodes, \& McGready, 2012; Fu \& Van Landingham, 2010; Jovic-Vranes, Vranes, Marinkovic, \& Cucic, 2005; Kebede, Alem, Mitike, Enquselassie, Berhane, Abebe, Ayele, Lemma, Assefa, \& Gebremichael, 2005; Roberts, Murphy, Chikovani, Makhashvili, Patel, \& McKee, 2014) The prevalence of daily heavy alcohol use (5 or more drinks) among adults ranged from 5.5\% among Burmese male refugees in Thailand(Ezard, Thiptharakun, Nosten, Rhodes, \& McGready, 2012) to 17\% among Vietnamese refugees who repatriated back to Vietnam.(Fu \& Van Landingham, 2010) A study of IDPs in Georgia found that $12 \%$ of men and $2 \%$ of women were classified as 
engaging in episodic heavy drinking (more than 60 grams of pure alcohol per drinking session in the past seven days).(Roberts, Murphy, Chikovani, Makhashvili, Patel, \& McKee, 2014)

Alcohol use in adolescents (aged $<18$ years) was reported from seven studies. (Harris, Levey, Borba, Gray, Carney, \& Henderson, 2012; Jovic-Vranes, Vranes, Marinkovic, \& Cucic, 2005; Kebede, Alem, Mitike, Enquselassie, Berhane, Abebe, Ayele, Lemma, Assefa, \& Gebremichael, 2005; Londono, Romero, \& Casas, 2012; Maksimovic, Backovic, Maksimovic, \& Kocijancic, 2011; O'Donnell \& Roberts, 2015; Okello, Nakimuli-Mpungu, Musisi, Broekaert, \& Derluyn, 2013) Twenty-five percent of the alcohol-drinking school students in Belgrade reported heavy drinking.(JovicVranes, Vranes, Marinkovic, \& Cucic, 2005) Among youths in Ethiopia, 19.3\% reported drinking on a weekly basis and $2.1 \%$ on a daily basis.(Kebede, Alem, Mitike, Enquselassie, Berhane, Abebe, Ayele, Lemma, Assefa, \& Gebremichael, 2005)

$\underline{\text { Risk-factors associated with harmful alcohol use }}$

The evidence on risk factors for harmful alcohol use is described below, presented in detail in Table 2 and synthesised in Table 3.

\section{Demographic factors}

Among risk factors associated with harmful alcohol use, the strongest evidence was for male gender. Nine studies found that men were significantly more likely to engage in harmful alcohol use compared to women.(Abu Qamar, Thabet, \& 
Vostanis, 2007; Ezard, Thiptharakun, Nosten, Rhodes, \& McGready, 2012; Harris, Levey, Borba, Gray, Carney, \& Henderson, 2012; Jovic-Vranes, Vranes, Marinkovic, \& Cucic, 2005; Kozaric-Kovacic, Ljubin, \& Grappe, 2000; Luitel, Jordans, Murphy, Roberts, \& McCambridge, 2013; Puertas, Rios, \& Valle, 2006; Roberts, Felix Ocaka, Browne, Oyok, \& Sondorp, 2011; Roberts, Murphy, Chikovani, Makhashvili, Patel, \& McKee, 2014) Only one study (of conflict-affected Ugandan secondary school students) found no significant association between gender and harmful alcohol use.(Okello, Nakimuli-Mpungu, Musisi, Broekaert, \& Derluyn, 2013)

Four studies examined the role of age in harmful alcohol use. Three studies observed that older age was associated with higher prevalence of harmful alcohol use in both adults and adolescents.(Harris, Levey, Borba, Gray, Carney, \& Henderson, 2012; Roberts, Felix Ocaka, Browne, Oyok, \& Sondorp, 2011; Roberts, Murphy, Chikovani, Makhashvili, Patel, \& McKee, 2014) One study with Vietnamese returnees found no significant association.(Fu \& Van Landingham, 2010)

Two studies examined the influence of education level and harmful alcohol use.(Fu \& Van Landingham, 2010; Jovic-Vranes, Vranes, Marinkovic, \& Cucic, 2005; Luitel, Jordans, Murphy, Roberts, \& McCambridge, 2013) A study of Bhutanese refugees in Nepal found that higher educational status had a protective effect on harmful alcohol use,(Luitel, Jordans, Murphy, Roberts, \& McCambridge, 2013) while the study with Vietnamese returnees found no significant association between education level and harmful alcohol use.(Fu \& Van Landingham, 2010) Evidence on other types of demographic factors was limited to a study of university students in the Gaza strip 
which observed that being single (rather than married) was associated with alcohol abuse.(Abu Qamar, Thabet, \& Vostanis, 2007).

Armed conflict and exposure to traumatic events

Seven studies examined the relationship between exposure to armed conflict and harmful alcohol use.(Bosnar, Stemberga, Cuculic, Zamolo, Stifter, \& Coklo, 2004; Kozaric-Kovacic, Ljubin, \& Grappe, 2000; Londono, Romero, \& Casas, 2012; Maksimovic, Backovic, Maksimovic, \& Kocijancic, 2011; O'Donnell \& Roberts, 2015; Roberts, Felix Ocaka, Browne, Oyok, \& Sondorp, 2011; Roberts, Murphy, Chikovani, Makhashvili, Patel, \& McKee, 2014) For three of these studies, armed conflict exposure was measured by the number of traumatic/war experiences. Two studies of IDPs in northern Uganda and Georgia found a significant association between cumulative trauma exposure and harmful alcohol use.(Roberts, Felix Ocaka, Browne, Oyok, \& Sondorp, 2011; Roberts, Murphy, Chikovani, Makhashvili, Patel, \& McKee, 2014) In the study of IDPs in northern Uganda, the authors also found a significant association between specific types of traumatic events including abduction, torture, and imprisonment with harmful alcohol use However, the third study that examined cumulative trauma exposure found no significant association between trauma and harmful alcohol use for either male or female IDPs in Croatia.(Kozaric-Kovacic, Ljubin, \& Grappe, 2000)

A study in Colombia observed that young adults exposed to conflict were significantly more likely to report harmful alcohol use $(O R=4.4, p=0.05)$ than those not exposed to conflict.(Londono, Romero, \& Casas, 2012) A study of refugee youth 
in Gambia compared the percentage of alcohol use between refugee youth and Gambian youth $(15.2 \%$ and $0.9 \%$ respectively, Chi2 $=47.54, p=0.001)$ but this study was limited by the extremely small sample of refugees $(\mathrm{N}=33)$.(O'Donnell \& Roberts, 2015)

Alcohol intoxication among suicide cases in Croatia was compared for pre-war, war and post-war periods through a case-series design. The authors found that the level of alcohol intoxication obtained in autopsy was significantly higher $(p<0.01)$ during wartime $(0.65 \mathrm{~g} / \mathrm{kg})$ compared to pre-war $(0.43 \mathrm{~g} / \mathrm{kg})$ and post-war $(0.54 \mathrm{~g} / \mathrm{kg})$ periods. The authors attributed this higher alcohol intoxication to conflict-related stressors.(Bosnar, Stemberga, Cuculic, Zamolo, Stifter, \& Coklo, 2004) A study of adolescents in Belgrade found no significant difference in alcohol consumption between IDPs and the host population.(Maksimovic, Backovic, Maksimovic, \& Kocijancic, 2011)

\section{Mental health}

Only four studies examined the association between harmful alcohol use and mental disorders.(Kozaric-Kovacic, Ljubin, \& Grappe, 2000; Puertas, Rios, \& Valle, 2006; Roberts, Felix Ocaka, Browne, Oyok, \& Sondorp, 2011; Roberts, Murphy, Chikovani, Makhashvili, Patel, \& McKee, 2014) The study of IDPs in Croatia found that alcohol dependence defined by the DSM-III R criteria was significantly more common $(p=0.029)$ in men with PTSD (69.6\%) than those without PTSD $(51.3 \%)$ (KozaricKovacic, Ljubin, \& Grappe, 2000). This association was not observed for women $(p=0.228)$. Men were also significantly more likely to have both harmful alcohol use and PTSD than women (69.6\% vs. $11.7 \%$; p<0.00)(Kozaric-Kovacic, Ljubin, \& 
Grappe, 2000) In the study of IDPs in Georgia, harmful alcohol use was significantly associated with depression (adjusted $\mathrm{OR}=2.65, \mathrm{p}=0.01$ ) but not with PTSD.(Roberts, Murphy, Chikovani, Makhashvili, Patel, \& McKee, 2014) The study of IDPs in Colombia found a non-significant association between excessive alcohol consumption and common mental disorders.(Puertas, Rios, \& Valle, 2006) The study of IDPs in northern Uganda found no significant association between harmful alcohol use with PTSD or depression.(Roberts, Felix Ocaka, Browne, Oyok, \& Sondorp, 2011) All of these studies used cross-sectional designs and so were unable to examine the causal directional relationship between alcohol use and mental disorders.

\section{Family and community influences}

The study of Bhutanese refugees in Nepal observed that a family history of alcohol use was associated with harmful alcohol use.(Luitel, Jordans, Murphy, Roberts, \& McCambridge, 2013) The study of IDPs in Georgia looked at the association between harmful alcohol use and a combination of community influences ('alcogenic factors') such as prevalence of alcohol advertisement, retail shops selling alcohol, and alcohol prices, and observed a unit increase in the combined alcogenic factors was associated with an increase in episodic heavy drinking among men (AOR 1.27, p=0.04).(Roberts, Murphy, Chikovani, Makhashvili, Patel, \& McKee, 2014)

In summary, the evidence on factors associated with harmful alcohol use is strongest for male gender, older age, and exposure to traumatic events. 
Tobacco and substance abuse

Three studies examined the association between alcohol use and harmful health behaviours such as tobacco smoking and substance abuse.(Jovic-Vranes, Vranes, Marinkovic, \& Cucic, 2005; Kebede, Alem, Mitike, Enquselassie, Berhane, Abebe, Ayele, Lemma, Assefa, \& Gebremichael, 2005; Luitel, Jordans, Murphy, Roberts, \& McCambridge, 2013) In the study of Bhutanese refugees in Nepal, smoking and tobacco use was also found to be significantly associated with harmful alcohol use (adjusted OR=2.1, p<0.01).(Luitel, Jordans, Murphy, Roberts, \& McCambridge, 2013) However, the study of IDPs in Georgia found no significant association between harmful alcohol use and tobacco use.(Roberts, Murphy, Chikovani, Makhashvili, Patel, \& McKee, 2014) In the study of Bhutanese refugees in Nepal, substance misuse was significantly associated with higher odds of harmful drinking (adjusted $\mathrm{OR}=10.77, \mathrm{p}<0.001$ ) compared to those did not report substance misuse. The study of adolescents in Belgrade found that $11.3 \%$ of regular alcohol drinkers also used both drugs.(Jovic-Vranes, Vranes, Marinkovic, \& Cucic, 2005) As these were all cross-sectional studies, no causal direction could be determined.

\section{Unprotected sex}

The study of youths from Ethiopia examined the association between alcohol use and unprotected sex. The authors found that unprotected sex was reported among $30 \%$ of the youths who drank alcohol weekly, significantly higher than those who did not drink $(10.2 \%)$ (adjusted OR=2.01, $\mathrm{p}<0.001)$. Unprotected sex was reported by 
$46.5 \%$ of those who drank daily (adjusted $\mathrm{OR}=3.05, \mathrm{p}<0.001) .($ Kebede, Alem, Mitike, Enquselassie, Berhane, Abebe, Ayele, Lemma, Assefa, \& Gebremichael, 2005)

\section{Violent behaviours}

Three studies looked at the association between harmful alcohol drinking and violent behaviours.(Saile, Ertl, Neuner, \& Catani, 2014; Saile, Neuner, Ertl, \& Catani, 2013; Sibai, Tohme, Beydoun, Kanaan, \& Sibai, 2009) A study of families in northern Uganda found an independent association between alcohol-related problems in male guardians and aggressive guardian-child parenting behaviours $(p=0.03)$.(Saile, Ertl, Neuner, \& Catani, 2014) The authors also found in a follow-up study that alcoholrelated problems in men were significantly predictive of the overall level of current partner violence $(p=0.03)$, and both psychological $(p=0.02)$ and physical $(p<0.01)$

partner violence experienced by women.(Saile, Neuner, Ertl, \& Catani, 2013) A study of adolescents in Lebanon found significantly higher odds of experiencing a physical fight among those who were currently using alcohol (adjusted $O R=1.78, p<0.05$ ), engaging in binge drinking (adjusted $\mathrm{OR}=4.18, \mathrm{p}<0.05$ ), or riding with a drunk driver (adjusted $O R=2.6, p<0.05$ ). Similarly, higher odds of weapon carrying were also found among those who were currently using alcohol (adjusted $O R=1.80, p<0.05$ ), binge drinking (adjusted OR=3.99, $\mathrm{p}<0.05$ ), and riding with a drunk driver (adjusted OR=2.77, p<0.05).(Sibai, Tohme, Beydoun, Kanaan, \& Sibai, 2009)

\section{School behaviour}

The study of adolescents in Belgrade observed that low commitment to school was higher among current drinkers (22\%) than non-current drinkers $(12 \%)(O R=2.095 \%$ 
Cl 1.2-3.6).(Jovic-Vranes, Vranes, Marinkovic, \& Cucic, 2005) The same study observed that current drinkers (22\%) more commonly bullied others than non-current drinkers (9\%) $(\mathrm{OR}=2.1,95 \% \mathrm{Cl} 1.1-4.2)$.

In summary, the evidence generally suggests that harmful alcohol use is likely to be associated other harmful health behaviours of tobacco and substance abuse, unprotected sex, violence, and poor school behaviour. However, the cross-sectional study designs prevent understanding the causal direction.

\section{Quality assessment}

Quality assessment was conducted using an adapted version of the NewcastleOttawa Scale which focuses on: selection of study groups; comparability of the groups; and ascertainment of exposure/outcome of interest. Overall, six studies $(27 \%)$ were rated as strong quality (8-10 stars), nine studies $(41 \%)$ were rated as moderate quality (5-7 stars), and seven studies (32\%) were rated as weak quality (04 stars). Half of the studies $(n=11)$ scored only 1 out of 3 stars on the study selection rating as there was no sample size calculation or no description of non-responders. Poor ratings were also noted in the assessment of comparability in studies that failed to control for confounders. For ascertainment of exposure/outcome, better ratings were recorded with appropriate statistical tests being used and valid assessment of exposure/outcome. However, there was a general lack of description of the exposure/outcome measurement tool or definitions used for harmful alcohol use. Examples of bias included potential selection bias due to weak sampling from use of non-randomised sampling, lack of sample size calculation and omission on details of non-responders. Information bias could also be present in those with no control for 
confounders or use of validated measurement tools. The interpretation of results due to varied definitions of harmful alcohol use as an outcome might have also contributed to reporting bias. Detailed results for each paper are presented in Online Appendix 4.

\section{DISCUSSION}

This systematic review yielded just 22 studies on harmful alcohol use among conflictaffected civilian populations in LMICs. Most of the studies were cross-sectional in design and so the temporal relationship between conflict and harmful alcohol use could not be reliably examined. Similarly, the causal relationships for factors associated with harmful alcohol use could not be readily determined. In addition, the quality of the studies was generally only moderate. It is also difficult to make comparisons with baseline populations as such baseline data rarely exist. This is all in marked contrast to the far stronger evidence-base on harmful alcohol use among military personnel (albeit in high-income countries).(Jones \& Fear, 2011)

Given the limited quantity and quality of the studies, evidence on factors associated with harmful alcohol use should be interpreted with caution. The strongest evidence was found for male gender as a predictor of higher prevalence of harmful alcohol use, a finding that is consistent with patterns of harmful alcohol use in non-conflictaffected populations.(WHO, 2011) Explanations for this include stigma and gendered societal roles on women drinking alcohol (and reporting drinking alcohol) that is common in many cultural settings globally,(Holmila \& Raitasalo, 2005) and more specifically to conflict-affected populations is the gendered-dynamics of coping in 
which men may be more likely to use avoidance-seeking strategies such as alcohol use.(Seguin \& Roberts, 2015) Several studies also observed associations between older age and lower educational status with harmful alcohol use, but no definitive conclusions can be drawn due to the limited number of studies and the reliance on cross-sectional designs. A limited number of studies examined alcohol use among adolescents in conflict settings and there is a need for more research on adolescent alcohol consumption patterns, access to alcohol, and alcohol marketing directed toward youth.

A number of studies observed significant associations between conflict exposure and harmful alcohol use, in terms of number and types of traumatic experiences, with a dose-response relationship suggested between higher trauma exposure and harmful alcohol use. However, few studies examined the association between PTSD or common mental disorders (CMDs) with harmful alcohol use. While evidence from high-income settings supports the link between harmful alcohol use and common mental disorders (Rehm, Room, Monteiro, Gmel, Graham, Rehn, Sempos, \& Jernigan, 2003) further evidence is required to better understand the aetiology for conflict-affected populations. Studies from stable settings have indicated a number of ways in which harmful alcohol use can increase the risk of mental disorders such as: negatively impacting on individual's socio-economic circumstances which may then lead to worse mental health; alcohol and mental disorders being linked by genetic factors relating to neurotransmitter functioning which increase the risk of mental disorders in the presence of heavy alcohol use; and alcohol use causing metabolic changes that increase the risk of mental disorders.(Boden \& Fergusson, 2011; Hasin \& Grant, 2002; Wang \& Patten, 2002) Other studies suggest that individuals with 
poor mental health are more prone to use alcohol as a negative form of coping with the effects of the symptoms of mental disorders.(Grant \& Hartford, 1995; Grant, Stewart, \& Mohr, 2009; Kuo, Gardner, Kendler, \& Prescott, 2006)

Furthermore, a limited number of studies observed harmful health behaviours such as risky sexual behaviours, tobacco smoking and substance use in conflict-affected populations. Although the number of studies looking at these factors is limited, the associations between alcohol use and harmful health behaviours such as risky sexual behaviour and substance misuse have been well established in non-conflict settings.(WHO, 2005)

Evidence exists on the links between alcohol use and interpersonal violence in highincome settings in the absence of armed conflict,(WHO, 2015a) but only three of the selected studies had looked at the association between harmful alcohol use and violent behaviour in conflict-affected populations. This is despite widespread concerns over sexual violence in such settings.(UN, 2014; WHO, 2006) All three studies found significant associations between harmful alcohol use and violent behaviours such as partner violence against women, aggressive parenting, physical fighting and weapon carrying. Further research on alcohol use is urgently required in this field.(Ezard, 2014)

The lack of evidence on access to treatment for harmful alcohol use is disappointing. It is also noteworthy that no intervention studies were identified. Brief interventions have demonstrated high levels of effectiveness and cost-effectiveness in stable, non- 
conflict, high-income settings,(Babor \& Higgins-Biddle, 2000; National Treatment Agency for Substance Misuse, 2007; WHO, 2001) and have been studied in lowincome settings.(Pal, Yadav, Mehta, \& Mohan, 2007; Tsai, Tsai, Lin, \& Chen, 2009) These interventions could potentially be adapted to lower-resource, conflict-affected settings; and qualitative work on feasibility has been done on this.(Ezard, 2010) More research is required to support interventions addressing harmful alcohol use among conflict-affected populations. Learning from high-income countries, other successful measures to reduce alcohol related harm which can be adapted include changes to the alcogenic environment. These can include controls on availability and promotion (Casswell \& Thamarangsi, 2009) in more stable settings such as with long-term forcibly displaced populations and post-conflict settings, although clearly requiring adaptation to settings where most alcohol production and sale is informal. Health system changes include early detection and treatment of alcohol use disorder (including the management of acute withdrawal syndromes) (Benegal, Chand, \& Obot, 2009) and treatment of common coexisting mental disorders (such as major depression) and physical disorders (such as hypertension and TB).(Casswell \& Thamarangsi, 2009) Harm reduction measures include environmental modification (such as drinking sites away from main roads to prevent accidental injury), and provision of condoms and behavioural change interventions to reduce alcoholrelated risky sexual behaviour. Communities can also be mobilised to promote treatment seeking.(Agani, Landau, \& Agani, 2010)

Experimental research designs are required to ascertain the feasibility, effectiveness and cost-effectiveness of such work. The heavily gendered nature of alcohol use and harm worldwide, including among conflict-affected civilians, suggests that interventions and research should be gender sensitive. Clearly research, particularly 
intervention research, is extremely challenging in conflict-affected settings. However, large numbers of intervention studies, including experimental study designs, have been conducted for mental disorders with conflict-affected populations in these conflict-affected contexts.(Blanchet, Roberts, Ramesh, Frison, Sistenich, \& et al., 2014) which suggests similar studies could be conducted for harmful alcohol use outcomes. In addition, there can be greater use of adapted randomised control trial designs, such as stepped wedge designs, that can offer a more pragmatic design for such settings.

The leading guidelines provide no details on the kinds of activities that should be conducted to address harmful alcohol use.(IASC, 2007; Sphere Project, 2011) However, some guidance exists on conducting rapid assessments of harmful alcohol use in humanitarian settings.(Ezard, Oppenheimer, Burton, Schilperoord, Macdonald, Adelekan, Sakarati, \& van Ommeren, 2011; UNHCR/WHO, 2008) Routine screening and interventions should be incorporated into the provision of health services. While evidence from more stable settings may be helpful in informing these activities and guidelines, evidence of interventions from conflictaffected settings is required given the specific contextual influences of conflict.

\section{Limitations}

The most significant limitation is the dearth of raw data available. The limited number of studies identified, with inconsistent definitions of harmful alcohol use and varied outcomes measured using a range of tools, prevent drawing conclusions from the study, particularly statistical ones. As a result, it is not possible to draw an 
overarching connection between conflict, risk factors, and harmful alcohol use. The predominance of cross-sectional studies also means it is not possible to understand the temporal nature of harmful alcohol use and the factors associated with it. Only English and Spanish language studies were used. We did not conduct inter-rate reliability measures between the two assessors. This review does not include any qualitative studies which could be useful to explore the perceptions of alcohol use and the impacts of conflict on its use, and the conflict-specific conditions and contextual influences on alcohol use. Nevertheless, the number of qualitative studies identified during bibliographic search was very limited $(\mathrm{N}=5)$.

\section{CONCLUSION}

The findings from this systematic review show that in some, but not all settings, harmful alcohol use is prevalent. The findings suggest an association between trauma exposure with harmful alcohol use. There is also some evidence on the association between harmful alcohol use and mental disorders but this is more mixed, and the causal direction between mental disorder and alcohol use cannot be established from the existing evidence. The findings also suggest greater harmful alcohol use among men and older age groups. There is also some evidence on the association between harmful alcohol use and other harmful behaviours. The review also identifies major gaps in the evidence base, and substantially more research is required to understand the scale of harmful alcohol use, key risk-factors, the causal relationship with mental disorders, and the effectiveness of interventions addressing harmful alcohol use among conflict-affected populations. 
Funding source: no funding was used for this review

\section{REFERENCES}

Abu Qamar, K., Thabet, A., \& Vostanis, P. (2007). Substance use among university students in the Gaza Strip. Arab Journal of Psychiatry, 18(1), 10-20.

Agani, F., Landau, J., \& Agani, N. (2010). Community-building before, during, and after times of trauma: the application of the LINC model of community resilience in Kosovo. Am J Orthopsychiatry, 80(1), 143-149. doi:

10.1111/j.1939-0025.2010.01017.x

Akinyemi, O. O., \& Owoaje, E. T. (2011). Comparison of mental health status among adult refugee and non-refugee populations in Oru-ljebu, Southwestern Nigeria. American Journal of Tropical Medicine and Hygiene, 1), 32-33.

Babor TF, Higgins-Biddle JC, Saunders JB, \& Monteiro MG (2001). AUDIT - Alcohol Use Disorders Identification Test: Guidelines for Use in Primary Care. Geneva: World Health Organization.

Babor, T. F., \& Higgins-Biddle, J. C. (2000). Alcohol screening and brief intervention: dissemination strategies for medical practice and public health. Addiction, 95(5), 677-686.

Bakke, O., \& Endal, D. (2010). Vested interests in addiction research and policy alcohol policies out of context: drinks industry supplanting government role in alcohol policies in sub-Saharan Africa. Addiction, 105(1), 22-28. doi: ADD2695 [pii] 10.1111/j.1360-0443.2009.02695.x

Baliunas, D., Rehm, J., Irving, H., \& Shuper, P. (2010). Alcohol consumption and risk of incident human immunodeficiency virus infection: a meta-analysis. Int $J$ Public Health, 55(3), 159-166. doi: 10.1007/s00038-009-0095-x

Benegal, V., Chand, P. K., \& Obot, I. S. (2009). Packages of care for alcohol use disorders in low- and middle-income countries. PLoS Med, 6(10), e1000170. doi: 10.1371/journal.pmed.1000170

Blanchet, K., Roberts, B., Ramesh, A., Frison, S., Sistenich, V., \& et al. (2014). An evidence review of research on health interventions in humanitarian crises. London: ELHRA.

Boden, J. M., \& Fergusson, D. M. (2011). Alcohol and depression. Addiction, 106(5), 906-914. doi: 10.1111/j.1360-0443.2010.03351.x

Bosnar, A., Stemberga, V., Cuculic, D., Zamolo, G., Stifter, S., \& Coklo, M. (2004). Suicide rate after the 1991-1995 War in Southwestern Croatia. Archives of Medical Research, 35(4), 344-347.

Brown, G., Langer, A., \& Stewart, F. (2011). A Typology of Post-Conflict Environments (Vol. CRPD Working Paper No. 1, pp. 22). Leuven: CRPD.

Buljan, D., Vrcek, D., Cekic-Arambasin, A., Karlovic, D., Zoricic, Z., \& Golik-Gruber, V. (2002). Posttraumatic stress disorder, alcohol dependence, and somatic disorders in displaced persons. Alcoholism, 38(1-2), 35-40.

Casswell, S., \& Thamarangsi, T. (2009). Reducing harm from alcohol: call to action. Lancet, 373(9682), 2247-2257. doi: 10.1016/S0140-6736(09)60745-5

Collier, P., \& Hoeffler, A. (2004). Aid, policy and growth in post-conflict societies. European Economic Review, 48, 1125-1145. 
CRED. (2013). People Affected by Conflict - Humanitarian needs in numbers. Brussles: Centre for Research on the Epidemiology of Disasters.

de Jong, J. T., Komproe, I. H., \& Van Ommeren, M. (2003). Common mental disorders in postconflict settings. Lancet, 361(9375), 2128-2130. doi: 10.1016/S0140-6736(03)13692-6

Demaio, A., Jamieson, J., Horn, R., de Courten, M., \& Tellier, S. (2013). Noncommunicable diseases in emergencies: a call to action. PLoS Curr, 5. doi: 10.1371/currents.dis.53e08b951d59ff913ab8b9bb51c4d0de

Deng, F., \& United Nations. (1998). Guiding Principles on Internal Displacement.

Ewing, J. A. (1984). Detecting alcoholism. The CAGE questionnaire. JAMA, 252(14), 1905-1907.

Ezard, N. (2012). Substance use among populations displaced by conflict: a literature review. Disasters, 36(3), 533-557. doi: 10.1111/j.14677717.2011.01261.x

Ezard, N. (2014). It's not just the alcohol: gender, alcohol use, and intimate partner violence in Mae La refugee camp, Thailand, 2009. Subst Use Misuse, 49(6), 684-693. doi: 10.3109/10826084.2013.863343

Ezard, N., Debakre, A. \& Catillon, R. (2010). Screening and brief intervention for high-risk alcoholuse in Mae La refugee camp,Thailand: a pilot project on the feasibility of training and implementation. Intervention, 8, 223-232.

Ezard, N., Oppenheimer, E., Burton, A., Schilperoord, M., Macdonald, D., Adelekan, M., Sakarati, A., \& van Ommeren, M. (2011). Six rapid assessments of alcohol and other substance use in populations displaced by conflict. Confl Health, 5(1), 1. doi: 10.1186/1752-1505-5-1

Ezard, N., Thiptharakun, S., Nosten, F., Rhodes, T., \& McGready, R. (2012). Risky alcohol use among reproductive-age men, not women, in Mae La refugee camp, Thailand, 2009. Conflict and health, 6(1), 7-7. doi: 10.1186/1752-15056-7

Fu, H., \& Van Landingham, M. J. (2010). Mental and Physical Health Consequences of Repatriation for Vietnamese Returnees: A Natural Experiment Approach. Journal of Refugee Studies, 23(2), 160-182. doi: 10.1093/jrs/feq012

G. B. D. Risk Factors Collaborators. (2015). Global, regional, and national comparative risk assessment of 79 behavioural, environmental and occupational, and metabolic risks or clusters of risks in 188 countries, 19902013: a systematic analysis for the Global Burden of Disease Study 2013. Lancet, 386(10010), 2287-2323. doi: 10.1016/S0140-6736(15)00128-2

Grant, B. F., \& Hartford, T. C. (1995). Comorbidity between DSM-IV alcohol use disorders and major depression: results of a national survey. Drug Alcohol Depend, 39(3), 197-206.

Grant, V. V., Stewart, S. H., \& Mohr, C. D. (2009). Coping-anxiety and copingdepression motives predict different daily mood-drinking relationships. Psychol Addict Behav, 23(2), 226-237. doi: 10.1037/a0015006

Harris, B. L., Levey, E. J., Borba, C. P., Gray, D. A., Carney, J. R., \& Henderson, D. C. (2012). Substance use behaviors of secondary school students in postconflict Liberia: A pilot study. International Journal of Culture and Mental Health, 5(3), 190-201.

Hasin, D. S., \& Grant, B. F. (2002). Major depression in 6050 former drinkers: association with past alcohol dependence. Arch Gen Psychiatry, 59(9), 794800. 
Herzog, R., Alvarez-Pasquin, M. J., Diaz, C., Del Barrio, J. L., Estrada, J. M., \& Gil, A. (2013). Are healthcare workers' intentions to vaccinate related to their knowledge, beliefs and attitudes? A systematic review. BMC Public Health, 13, 154. doi: 10.1186/1471-2458-13-154

Hewitt RamíRez, N., Gantiva DÍAz, C. A., Vera Maldonado, A., Cuervo RodríGuez, M. P., Nelly Liliam, H. O., JuÁRez, F., \& Parada BaÑOs, A. J. (2014). AFECTACIONES PSICOLÓGICAS DE NIÑOS Y ADOLESCENTES EXPUESTOS AL CONFLICTO ARMADO EN UNA ZONA RURAL DE COLOMBIA. [Psychological effects on children and adolescents exposed to armed conflict in a rural area of colombia

AfetaÇÕes psicolÓgicas de crianÇas e adolescentes expostos ao conflito armado em uma zona rural da colÔmbia]. Acta Colombiana de Psicología, 17(1), 7989.

Holmila, M., \& Raitasalo, K. (2005). Gender differences in drinking: why do they still exist? Addiction, 100(12), 1763-1769. doi: 10.1111/j.1360-0443.2005.01249.x

IASC. (2007). IASC Guidelines on Mental Health and Psychosocial Support in Emergency Settings. Geneva: IASC.

IDMC. (2015). Global Overview 2015: People internally displaced by conflict and violence. Geneva: Internal Displacement Monitoring Centre.

Jones, E., \& Fear, N. T. (2011). Alcohol use and misuse within the military: a review. Int Rev Psychiatry, 23(2), 166-172. doi: 10.3109/09540261.2010.550868

Jovic-Vranes, A. S., Vranes, B., Marinkovic, J., \& Cucic, V. (2005). Adolescent substance abuse, the importance of family, school and peers: data from the health behaviour in school children. Sozial- und Praventivmedizin, 50(2), 119124.

Kebede, D., Alem, A., Mitike, G., Enquselassie, F., Berhane, F., Abebe, Y., Ayele, R., Lemma, W., Assefa, T., \& Gebremichael, T. (2005). Khat and alcohol use and risky sex behaviour among in-school and out-of-school youth in Ethiopia. BMC Public Health, 5, 109. doi: 10.1186/1471-2458-5-109

Kehle, S. M., Ferrier-Auerbach, A. G., Meis, L. A., Arbisi, P. A., Erbes, C. R., \& Polusny, M. A. (2012). Predictors of postdeployment alcohol use disorders in National Guard soldiers deployed to Operation Iraqi Freedom. Psychol Addict Behav, 26(1), 42-50. doi: 10.1037/a0024663

Kline, A., Weiner, M. D., Ciccone, D. S., Interian, A., St Hill, L., \& Losonczy, M. (2014). Increased risk of alcohol dependency in a cohort of National Guard troops with PTSD: a longitudinal study. J Psychiatr Res, 50, 18-25. doi: 10.1016/j.jpsychires.2013.11.007

Kozaric-Kovacic, D., Ljubin, T., \& Grappe, M. (2000). Comorbidity of posttraumatic stress disorder and alcohol dependence in displaced persons. Croatian Medical Journal, 41(2), 173-178.

Kuo, P. H., Gardner, C. O., Kendler, K. S., \& Prescott, C. A. (2006). The temporal relationship of the onsets of alcohol dependence and major depression: using a genetically informative study design. Psychol Med, 36(8), 1153-1162. doi: $10.1017 /$ S0033291706007860

Levy, B. S., \& Sidel, V. W. (2009). Health effects of combat: A life-course perspective. Annual Review of Public Health, 30, 123-136.

Lo, J., Patel, P., \& Roberts, B. (2015). A systematic review on tobacco use among civilian populations affected by armed conflict. Tob Control. doi: 10.1136/tobaccocontrol-2014-052054 
Londono, A., Romero, P., \& Casas, G. (2012). The association between armed conflict, violence and mental health: a cross sectional study comparing two populations in Cundinamarca department, Colombia. Conflict and health, 6(1), 12-12. doi: 10.1186/1752-1505-6-12

Luitel, N. P., Jordans, M., Murphy, A., Roberts, B., \& McCambridge, J. (2013). Prevalence and patterns of hazardous and harmful alcohol consumption assessed using the AUDIT among Bhutanese refugees in Nepal. Alcohol \& Alcoholism, 48(3), 349-355.

Maksimovic, M., Backovic, D., Maksimovic, J., \& Kocijancic, R. (2011). Socioeconomic status and psychosocial functioning of internally displaced adolescents and adolescents from Belgrade. Int J Public Health, 56(3), 305310.

Moher, D., Liberati, A., Tetzlaff, J., Altman, D. G., \& Group, P. (2009). Preferred reporting items for systematic reviews and meta-analyses: the PRISMA statement. BMJ, 339, b2535. doi: 10.1136/bmj.b2535

National Treatment Agency for Substance Misuse. (2007). Review of the effectiveness of treatment for alcohol problems.: National Health Service (UK).

O'Donnell, D. A., \& Roberts, W. C. (2015). Experiences of Violence, Perceptions of Neighborhood, and Psychosocial Adjustment Among West African Refugee Youth. International Perspectives in Psychology: Research, Practice, Consultation, 4, 1-18.

Okello, J., Nakimuli-Mpungu, E., Musisi, S., Broekaert, E., \& Derluyn, I. (2013). Warrelated trauma exposure and multiple risk behaviors among school-going adolescents in Northern Uganda: The mediating role of depression symptoms. Journal of Affective Disorders, 151(2), 715-721.

Pal, H. R., Yadav, D., Mehta, S., \& Mohan, I. (2007). A comparison of brief intervention versus simple advice for alcohol use disorders in a North India community-based sample followed for 3 months. Alcohol Alcohol, 42(4), 328332. doi: 10.1093/alcalc/agm009

Priebe, S., Bogic, M., Ajdukovic, D., Franciskovic, T., Galeazzi, G. M., Kucukalic, A., Lecic-Tosevski, D., Morina, N., Popovski, M., Wang, D., \& Schuetzwohl, M. (2010). Mental Disorders Following War in the Balkans A Study in 5 Countries. Archives of General Psychiatry, 67(5), 518-528.

Puertas, G., Rios, C., \& Valle, H. d. (2006). The prevalence of common mental disorders in urban slums with displaced persons in Colombia. Revista Panamericana de Salud Publica/Pan American Journal of Public Health, 20(5), 324-330.

Rehm, J., Mathers, C., Popova, S., Thavorncharoensap, M., Teerawattananon, Y., \& Patra, J. (2009). Global burden of disease and injury and economic cost attributable to alcohol use and alcohol-use disorders. Lancet, 373(9682), 2223-2233. doi: 10.1016/S0140-6736(09)60746-7

Rehm, J., Room, R., Monteiro, M., Gmel, G., Graham, K., Rehn, N., Sempos, C. T., \& Jernigan, D. (2003). Alcohol as a risk factor for global burden of disease. Eur Addict Res, 9(4), 157-164. doi: 72222

Rehm, J., Samokhvalov, A. V., Neuman, M. G., Room, R., Parry, C., Lonnroth, K., Patra, J., Poznyak, V., \& Popova, S. (2009). The association between alcohol use, alcohol use disorders and tuberculosis (TB). A systematic review. BMC Public Health, 9, 450. doi: 10.1186/1471-2458-9-450 
Roberts, B., \& Ezard, N. (2015). Why are we not doing more for alcohol use disorder among conflict-affected populations? Addiction, 110(6), 889-890. doi: 10.1111/add.12869

Roberts, B., Felix Ocaka, K., Browne, J., Oyok, T., \& Sondorp, E. (2011). Alcohol disorder amongst forcibly displaced persons in northern Uganda. Addictive Behaviors, 36(8), 870-873.

Roberts, B., Murphy, A., Chikovani, I., Makhashvili, N., Patel, V., \& McKee, M. (2014). Individual and community level risk-factors for alcohol use disorder among conflict-affected persons in Georgia. PLoS ONE, 9(5).

Robins, L. N., Wing, J., Wittchen, H. U., Helzer, J. E., Babor, T. F., Burke, J., Farmer, A., Jablenski, A., Pickens, R., Regier, D. A., \& et al. (1988). The Composite International Diagnostic Interview. An epidemiologic Instrument suitable for use in conjunction with different diagnostic systems and in different cultures. Arch Gen Psychiatry, 45(12), 1069-1077.

Saile, R., Ertl, V., Neuner, F., \& Catani, C. (2014). Does war contribute to family violence against childrenalpha Findings from a two-generational multiinformant study in Northern Uganda. Child Abuse and Neglect, 38(1), 135146.

Saile, R., Neuner, F., Ertl, V., \& Catani, C. (2013). Prevalence and predictors of partner violence against women in the aftermath of war: a survey among couples in Northern Uganda. Social Science \& Medicine, 86, 17-25.

Seguin, M., \& Roberts, B. (2015). Coping strategies among conflict-affected adults in low- and middle-income countries: A systematic literature review. Glob Public Health, 1-19. doi: 10.1080/17441692.2015.1107117

Sheehan, D. V., Lecrubier, Y., Sheehan, K. H., Amorim, P., Janavs, J., Weiller, E., Hergueta, T., Baker, R., \& Dunbar, G. C. (1998). The Mini-International Neuropsychiatric Interview (M.I.N.I.): the development and validation of a structured diagnostic psychiatric interview for DSM-IV and ICD-10. J Clin Psychiatry, 59 Suppl 20, 22-33;quiz 34-57.

Shuper, P. A., Joharchi, N., Irving, H., \& Rehm, J. (2009). Alcohol as a correlate of unprotected sexual behavior among people living with HIVIAIDS: review and meta-analysis. AIDS Behav, 13(6), 1021-1036. doi: 10.1007/s10461-0099589-z

Sibai, T., Tohme, R. A., Beydoun, H. A., Kanaan, N., \& Sibai, A. M. (2009). Violent behavior among adolescents in post-war Lebanon: the role of personal factors and correlation with other problem behaviors. Journal of Public Health, 31(1), 39-46.

Sphere Project. (2011). Sphere Handbook: Humanitarian Charter for and Minimum Standards in Disaster Response. Geneva: Sphere Project.

Steel, Z., Chey, T., Silove, D., Marnane, C., Bryant, R. A., \& van Ommeren, M. (2009). Association of torture and other potentially traumatic events with mental health outcomes among populations exposed to mass conflict and displacement: a systematic review and meta-analysis. JAMA, 302(5), 537549. doi: 10.1001/jama.2009.1132

The World Bank. (2015). How does the World Bank classify countries. Retrieved 23/04, 2015, from

https://datahelpdesk.worldbank.org/knowledgebase/articles/378834-howdoes-the-world-bank-classify-countries

Tsai, Y. F., Tsai, M. C., Lin, Y. P., \& Chen, C. Y. (2009). Brief intervention for problem drinkers in a Chinese population: a randomized controlled trial in a 
hospital setting. Alcohol Clin Exp Res, 33(1), 95-101. doi: 10.1111/j.15300277.2008.00815.x

UN. (1951). Convention relating to the Status of Refugees. Retrieved 27/04, 2015, from

http://www.ohchr.org/EN/Professionallnterest/Pages/StatusOfRefugees.aspx

UN. (2014). Stop Rape Now: UN Action Against Sexual Violence in Conflict: Progress Report 2013-2014.

UNHCR. (2014). UNHCR Mid-Year Trends 2014 (pp. 23). Geneva: United Nations High Comissioners for Refugees.

UNHCRMHO. (2008). Rapid Assessment of Alcohol and Other Substance Use in Conflict-affected and Displaced Populations: A Field Guide: UNHCR/WHO.

Uppsala University. (2015). UCPD Conflict Encyclopedia. Retrieved 20 August 2015, from http://www.ucdp.uu.se/gpdatabase/search.php

Wallace, K., \& Roberts, B. (2014). An exploration of the alcohol policy environment in post-conflict countries. Alcohol Alcohol, 49(3), 356-362. doi:

10.1093/alcalc/agt142

Wang, J., \& Patten, S. B. (2002). Prospective study of frequent heavy alcohol use and the risk of major depression in the Canadian general population. Depress Anxiety, 15(1), 42-45.

Weaver, H., \& Roberts, B. (2010). Drinking and displacement: a systematic review of the influence of forced displacement on harmful alcohol use. Subst Use Misuse, 45(13), 2340-2355. doi: 10.3109/10826081003793920

Weitzman, E. R., \& Chen, Y. Y. (2005). Risk modifying effect of social capital on measures of heavy alcohol consumption, alcohol abuse, harms, and secondhand effects: national survey findings. J Epidemiol Community Health, 59(4), 303-309. doi: 10.1136/jech.2004.024711

Wells, G., Shea, B., O'Connell, D., Peterson, J., Welch, V., Losos, M., \& Tugwell, P. (2014). The Newcastle-Ottawa Scale (NOS) for assessing the quality of nonrandomised studies in meta-analyses. 2015, from http://www.ohri.ca/programs/clinical epidemiology/oxford.asp

WHO. (2001). Brief Intervention for For Hazardous and Harmful Drinking: A Manual for Use in Primary Care. . Geneva: World Health Organisation.

WHO. (2005). Alcohol Use and Sexual Risk Behaviour: A Cross-Cultural Study in Eight Countries. from http://www.who.int/substance abuse/publications/alcohol sexual risk crossc ultural.pdf

WHO. (2006). Intimate Partner Violence and Alcohol. Geneva: World Health Organisation.

WHO. (2011). Global status report on alcohol and health. Geneva: World Health Organization.

WHO. (2015a). Interpersonal Violence and Alcohol. Geneva: World Health Organisation.

WHO. (2015b). Management of substance abuse: Alcohol. 2015, from http://www.who.int/substance abuse/facts/alcohol/en/ 


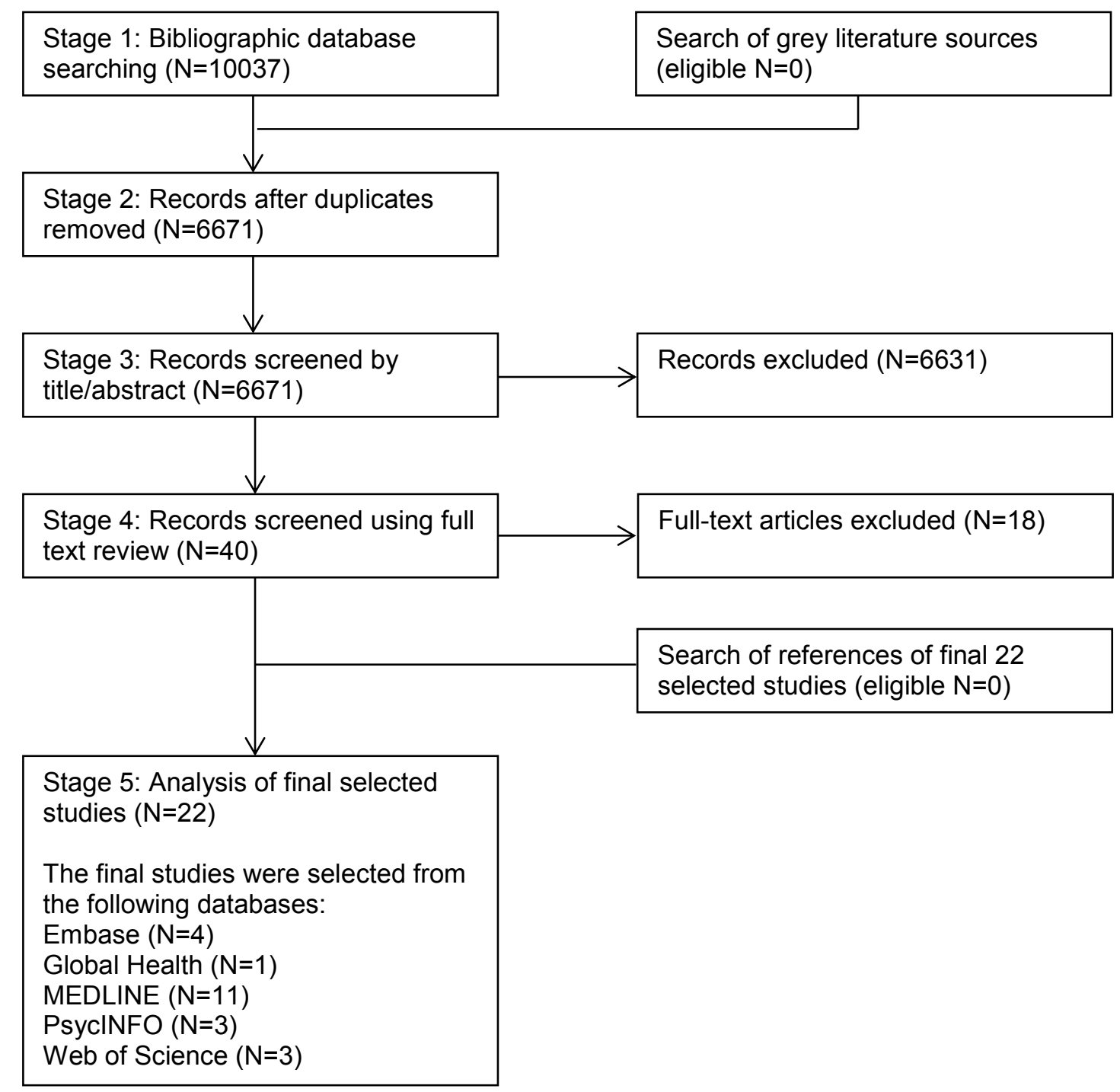

Figure 1: Results of study selection process 
Table 1: Summary of studies on harmful alcohol use

\begin{tabular}{|c|c|c|c|}
\hline (Author) & Study design and sample & Harmful alcohol use outcomes & Study quality* \\
\hline (Abu Qamar, Thabet, \& Vostanis, 2007) & $\begin{array}{l}\text { Cross-sectional study of } 1007 \text { students } \\
\text { from four universities at Gaza Strip }\end{array}$ & $\begin{array}{l}\text { Abused alcohol (undefined) in the past } 12 \text { months: } 13(1.2 \%) \text { students } \\
\text { Male }=12(2.4 \%) \text { vs female }=1(0.2 \%)\end{array}$ & Weak \\
\hline (Akinyemi \& Owoaje, 2011) & $\begin{array}{l}\text { Cross-sectional study of } 971 \text { refugees } \\
\text { and host population in Nigeria }\end{array}$ & Alcohol abuse (MINI questionnaire): $19 \%$ among refugees vs $13.5 \%$ among residents $(p<0.05)$ & Moderate \\
\hline $\begin{array}{l}\text { (Bosnar, Stemberga, Cuculic, Zamolo, } \\
\text { Stifter, \& Coklo, 2004) }\end{array}$ & $\begin{array}{l}\text { Case study of } 853 \text { suicide cases in } \\
\text { Croatia between } 1985-2000\end{array}$ & Level of alcohol intoxication ( $\mathrm{g} / \mathrm{kg})$ & Weak \\
\hline $\begin{array}{l}\text { (Ezard, Thiptharakun, Nosten, Rhodes, } \\
\text { \& McGready, 2012) }\end{array}$ & $\begin{array}{l}\text { Mixed methods study (cross-sectional } \\
\text { survey and informant interview) of } 636 \\
\text { Burmese women from antenatal clinic in } \\
\text { Mae La refugee camp, Thailand (only } \\
\text { quantitative findings reported) }\end{array}$ & $\begin{array}{l}\text { AUDIT (question 3) } \\
\text { Binge drinking: women }=0.2 \% \text {, men }=24.4 \% \\
\text { Freq. of consumption of } 6 \text { drinks or more. Women (self-report): never=98.1\%; <monthly=1.7\%; } \\
\text { monthly }=0.2 \% \text {. Men (secondary report): never }=56,3 \% ;<\text { monthly=19.3\%; monthly=12.4\%; } \\
\text { weekly }=6,4 \% \text {; daily }=5.5 \%\end{array}$ & Moderate \\
\hline (Fu \& Van Landingham, 2010) & $\begin{array}{l}\text { Cross-sectional study of } 709 \text { Vietnamese } \\
\text { refugee returnees (and never leavers and } \\
\text { immigrants) }\end{array}$ & $\begin{array}{l}\text { Binge drinking ( } 5 \text { shots or more/day or in a single episode): returnees=17\%, never leavers }=16 \% \text {, } \\
\text { immigrants }=16 \%\end{array}$ & Weak \\
\hline $\begin{array}{l}\text { (Harris, Levey, Borba, Gray, Carney, \& } \\
\text { Henderson, 2012) }\end{array}$ & $\begin{array}{l}\text { Cross-sectional study of } 802 \text { secondary } \\
\text { school students in Monrovia, Liberia }\end{array}$ & Alcohol use $=51 \%$ Male $58.4 \%$, female $43.9 \%$ & Weak \\
\hline $\begin{array}{l}\text { (Hewitt RamíRez, Gantiva DíAz, Vera } \\
\text { Maldonado, Cuervo RodríGuez, Nelly } \\
\text { Liliam, JuÁRez, \& Parada BaÑOs, } \\
\text { 2014) }\end{array}$ & $\begin{array}{l}\text { Cross-sectional study of } 284 \text { children and } \\
\text { adolescents in rural area of Colombia }\end{array}$ & $\begin{array}{l}\text { Harmful alcohol use: } 1 \% \text {; risky consumption=6\%; moderate consumption }=93 \% \\
\text { Note: assumed to be among current alcohol consumers but not clarified. } \\
\text { Note: Study uses CAGE questionnaire but this produces a binary outcome of alcohol dependence. } \\
\text { The authors do not explain their categories of harmful/risky/moderate. }\end{array}$ & Moderate \\
\hline $\begin{array}{l}\text { (Jovic-Vranes, Vranes, Marinkovic, \& } \\
\text { Cucic, 2005) }\end{array}$ & $\begin{array}{l}\text { Cross-sectional study of } 1536 \\
\text { adolescents from } 65 \text { schools in Belgrade }\end{array}$ & $\begin{array}{l}\text { Weekly alcohol consumption: } 5.6 \% \text { students consumed weekly, with } 25 \% \text { of them having } 5 \text { or } \\
\text { more drinks per session }\end{array}$ & Moderate \\
\hline $\begin{array}{l}\text { (Kebede, Alem, Mitike, Enquselassie, } \\
\text { Berhane, Abebe, Ayele, Lemma, } \\
\text { Assefa, \& Gebremichael, 2005) }\end{array}$ & $\begin{array}{l}\text { Cross-sectional study of } 20434 \text { in-school } \\
\text { and out-of-school youths from Ethiopia }\end{array}$ & $\begin{array}{l}\text { Alcohol intake: none or occasional drinking }=78.7 \% \text {; on a weekly basis= } 19.3 \% \text {; on a daily } \\
\text { basis }=2.1 \%\end{array}$ & Moderate \\
\hline $\begin{array}{l}\text { (Kozaric-Kovacic, Ljubin, \& Grappe, } \\
2000)\end{array}$ & $\begin{array}{l}\text { Cross-sectional study of } 368 \text { IDPs in } \\
\text { Croatia }\end{array}$ & Alcohol dependence (measured by CAGE and DSM IV): Men 60.5\% vs women $8.1 \%$ & Moderate \\
\hline (Londono, Romero, \& Casas, 2012) & $\begin{array}{l}\text { Cross-sectional study of } 84 \text { young adults } \\
\text { from two communities in Colombia }\end{array}$ & $\begin{array}{l}\text { Alcohol abuse (undefined): Among those exposed to conflict=54.54\%; among those with no } \\
\text { exposure to conflict=21.42\%. }\end{array}$ & Weak \\
\hline
\end{tabular}




\begin{tabular}{|c|c|c|c|}
\hline $\begin{array}{l}\text { (Luitel, Jordans, Murphy, Roberts, \& } \\
\text { McCambridge, 2013) }\end{array}$ & $\begin{array}{l}\text { Cross-sectional study of } 8021 \text { Bhutanese } \\
\text { refugees in Nepal }\end{array}$ & $\begin{array}{l}\text { Hazardous drinking (AUDIT score } \geq 8 \text { ): all sample }=2.8 \% \text {; male }=5.1 \% \text {; female }=0.6 \% \text {. } \\
\text { Alcohol dependence (AUDIT score }>19 \text { ): all sample }=0.6 \% \text {; male }=1.2 \% \text {; female }=0.1 \%\end{array}$ & Strong \\
\hline $\begin{array}{l}\text { (Maksimovic, Backovic, Maksimovic, \& } \\
\text { Kocijancic, 2011) }\end{array}$ & $\begin{array}{l}\text { Cross-sectional study of } 560 \text { adolescents } \\
\text { in Belgrade (IDPs \& host) }\end{array}$ & Alcohol use: IDPs=56.3\%; host $=70.8 \%$ & Weak \\
\hline (O'Donnell \& Roberts, 2015) & $\begin{array}{l}\text { Cross-sectional study of } 943 \text { secondary } \\
\text { school students in Gambia }\end{array}$ & Alcohol use: refugee youth=15.2\%; Gambian youth $=0.9 \%$ & Moderate \\
\hline $\begin{array}{l}\text { (Okello, Nakimuli-Mpungu, Musisi, } \\
\text { Broekaert, \& Derluyn, 2013) }\end{array}$ & $\begin{array}{l}\text { Cross-sectional study of } 551 \text { secondary } \\
\text { school students in northern Uganda }\end{array}$ & Alcohol use: $5.26 \%$; male=4.23\%; female=6.37\%. & Weak \\
\hline $\begin{array}{l}\text { (Priebe, Bogic, Ajdukovic, Franciskovic, } \\
\text { Galeazzi, Kucukalic, Lecic-Tosevski, } \\
\text { Morina, Popovski, Wang, \& } \\
\text { Schuetzwohl, 2010) }\end{array}$ & $\begin{array}{l}\text { Cross-sectional study of } 3313 \text { adults from } \\
\text { Bosnia-Herzegovina, Croatia, Kosovo, } \\
\text { Macedonia and Serbia }\end{array}$ & $\begin{array}{l}\text { Alcohol dependence (MINI): Bosnia=1.7\% (SE 0.5), Croatia=2.3\% (SE 0.6), Kosovo=1.5\% (SE } \\
0.5) \text {, Macedonia=0\%, Serbia=4.6\% (SE 0.8). } \\
\text { Alcohol abuse (MINI): Bosnia=3\% (SE 0.7), Croatia=2.8\% (SE 0.6), Kosovo=0.3\% (SE 0.2), } \\
\text { Macedonia=0.3\% (SE0.2), Serbia=2.7\% (SE0.6) }\end{array}$ & Moderate \\
\hline (Puertas, Rios, \& Valle, 2006) & $\begin{array}{l}\text { Cross-sectional study of } 878 \text { IDPs in } \\
\text { urban slums in Colombia }\end{array}$ & Excessive alcohol use (SRQ): Overall=13.6\%, men $=29.0 \%$, women $=6.4 \%$ & Strong \\
\hline $\begin{array}{l}\text { (Roberts, Felix Ocaka, Browne, Oyok, \& } \\
\text { Sondorp, 2011) }\end{array}$ & $\begin{array}{l}\text { Cross-sectional study of } 1206 \text { IDPs in } \\
\text { northern Uganda }\end{array}$ & $\begin{array}{l}\text { Alcohol use disorder (AUDIT score } \geq 8): \text { men }=32.4 \% \text { vs women }=7.1 \% \\
\text { Mean AUDIT score: } \text { men=5.8, women=1.3 }\end{array}$ & Strong \\
\hline $\begin{array}{l}\text { (Roberts, Murphy, Chikovani, } \\
\text { Makhashvili, Patel, \& McKee, 2014) }\end{array}$ & $\begin{array}{l}\text { Cross-sectional study of } 3600 \text { IDPs in } \\
\text { Georgia }\end{array}$ & $\begin{array}{l}\text { Current alcohol consumption: men=71\% vs women=16\% } \\
\text { Episodic heavy drinking: men }=12 \% \text { vs women }=2 \% \\
\text { Hazardous drinking (AUDIT } \geq 8) \text { : men=28\%; } 1 \% \text { women } \\
\text { Frequency of drinking >once a week: men=14\%; women }=<1 \% \\
\text { Volume of pure alcohol consumption per year: men=13.12L; women }=1.85 \mathrm{~L}\end{array}$ & Strong \\
\hline (Saile, Neuner, Ertl, \& Catani, 2013) & $\begin{array}{l}\text { Cross-sectional study of } 230 \text { couples in } \\
\text { northern Uganda }\end{array}$ & Alcohol-related problem with violence & Strong \\
\hline (Saile, Ertl, Neuner, \& Catani, 2014) & $\begin{array}{l}\text { Cross-sectional study of } 1037 \text { families in } \\
\text { northern Uganda }\end{array}$ & Alcohol-related problem with aggressive parenting & Strong \\
\hline $\begin{array}{l}\text { (Sibai, Tohme, Beydoun, Kanaan, \& } \\
\text { Sibai, 2009) }\end{array}$ & $\begin{array}{l}\text { Cross-sectional study of } 827 \text { adolescents } \\
\text { in Beirut, Lebanon }\end{array}$ & Alcohol related problem physical fight, binge drinking & Moderate \\
\hline \multicolumn{4}{|c|}{$\begin{array}{l}\text { AUDIT= Alcohol Use Disorders Identification Test; CAGE=assessment for alcohol abuse - Concern/Cut-down, Anger, Guilt, and Eye-opener; mSASQ=modified Single Alcohol Screening Questionnaire; } \\
\text { MINI=Mini International Neuropsychiatric Interview } \\
\text { (N/A=Not applicable) } \\
\text { * Study quality rating based on an adapted version of Newcastle-Ottawa Scale (Wells, Shea, O'Connell, Peterson, Welch, Losos, \& Tugwell, 2014), with 0-4 stars=weak; 5-7 starts=moderate; and 8-10 } \\
\text { stars=strong (see Online Appendix } 4 \text { for further details). }\end{array}$} \\
\hline
\end{tabular}




\section{Table 2: Evidence on factors associated with harmful alcohol use}

\begin{tabular}{|c|c|c|c|c|}
\hline (Author)/study setting & Demographics & Conflict and trauma exposure & Mental disorders & Other factors \\
\hline $\begin{array}{l}\text { (Abu Qamar, Thabet, \& Vostanis, } \\
\text { 2007) } \\
\text { University students in the Gaza } \\
\text { Strip }\end{array}$ & $\begin{array}{l}\text { Alcohol abuse } \\
\text { Gender: Male>female }(\text { Chi2 }=9.676, p=0.01) \\
\text { Unmarried>married }\left(\text { Chi }^{2}=17.82, p=0.01\right)\end{array}$ & $\mathrm{N} / \mathrm{A}$ & $\mathrm{N} / \mathrm{A}$ & $\mathrm{N} / \mathrm{A}$ \\
\hline $\begin{array}{l}\text { (Bosnar, Stemberga, Cuculic, } \\
\text { Zamolo, Stifter, \& Coklo, 2004) } \\
\text { Case study of } 853 \text { suicide cases in } \\
\text { Croatia }\end{array}$ & $\mathrm{N} / \mathrm{A}$ & $\begin{array}{l}\text { Average alcohol intoxication at time of suicide: } \\
\text { pre-war } 0.43 \mathrm{~g} / \mathrm{kg} \text {; during war } 0.65 \mathrm{~g} / \mathrm{kg} \text {; post-war } \\
0.54 \mathrm{~g} / \mathrm{kg}(\mathrm{p}<0.01)\end{array}$ & $\mathrm{N} / \mathrm{A}$ & $\mathrm{N} / \mathrm{A}$ \\
\hline $\begin{array}{l}\text { (Ezard, Thiptharakun, Nosten, } \\
\text { Rhodes, \& McGready, 2012) } \\
\text { Burmese women in antenatal clinic } \\
\text { in Mae La refugee camp, Thailand }\end{array}$ & $\begin{array}{l}\text { Gender: male>female for risky drinking } \\
(p<0.001) \\
\text { Age: Risky drinking more likely to be } \\
\text { reported in men }>25 \text { y.0. than men under } \\
25 \text { y.0. }(p<0.05)\end{array}$ & $\mathrm{N} / \mathrm{A}$ & $\mathrm{N} / \mathrm{A}$ & $\mathrm{N} / \mathrm{A}$ \\
\hline $\begin{array}{l}\text { (Fu \& Van Landingham, 2010) } \\
\text { Vietnamese refugee returnees. }\end{array}$ & $\begin{array}{l}\text { No significant association of age, marital } \\
\text { status, education and occupation with binge } \\
\text { drinking }\end{array}$ & $\mathrm{N} / \mathrm{A}$ & N/A & $\mathrm{N} / \mathrm{A}$ \\
\hline $\begin{array}{l}\text { (Harris, Levey, Borba, Gray, } \\
\text { Carney, \& Henderson, 2012) } \\
\text { Secondary school students in } \\
\text { Monrovia, Liberia }\end{array}$ & $\begin{array}{l}\text { Gender: Male }>\text { female }\left(C h i^{2}=15.767,\right. \\
p<0.001) \text {, but not significant in terms of } \\
\text { frequency of consumption or drinking along } \\
\text { Age: Older age group more likely to } \\
\text { consume alcohol }(p=0.002), \text { drunk alone } \\
(0=0.017) \text {, drink } \geq \text { per week }(p=0.001)\end{array}$ & $\mathrm{N} / \mathrm{A}$ & $\mathrm{N} / \mathrm{A}$ & $\mathrm{N} / \mathrm{A}$ \\
\hline $\begin{array}{l}\text { (Jovic-Vranes, Vranes, Marinkovic, } \\
\& \text { Cucic, 2005) } \\
\text { Adolescents from } 65 \text { schools in } \\
\text { Belgrade }\end{array}$ & $\begin{array}{l}\text { Gender: Male>female reported to having } \\
\text { 'been drunk': }(p=<0.05)\end{array}$ & $\mathrm{N} / \mathrm{A}$ & N/A & $\begin{array}{l}\text { Low commitment to school: } 22 \% \text { among current } \\
\text { alcohol users vs } 12 \% \text { non-users (OR=2.0 } 95 \% \\
\text { Cl 1.2-3.6). } \\
\text { Bullying others at school: } 22 \% \text { among current } \\
\text { users vs } 9 \% \text { non-current users (OR=2.1, } 95 \% \\
\mathrm{Cl} 1.1-4.2 \text { ). }\end{array}$ \\
\hline $\begin{array}{l}\text { (Kebede, Alem, Mitike, } \\
\text { Enquselassie, Berhane, Abebe, } \\
\text { Ayele, Lemma, Assefa, \& } \\
\text { Gebremichael, 2005) Youths from } \\
\text { Ethiopia }\end{array}$ & $\mathrm{N} / \mathrm{A}$ & $\mathrm{N} / \mathrm{A}$ & $\mathrm{N} / \mathrm{A}$ & $\begin{array}{l}\text { Unprotected sex: Association of alcohol intake } \\
\text { with (reference group is no intake }(10.2 \% \\
\text { prevalence)): }\end{array}$ \\
\hline
\end{tabular}




\begin{tabular}{|c|c|c|c|c|}
\hline & & & & $\begin{array}{l}\text { Weekly intake, } 30 \% \text { prevalence, } A O R=2.02 \text {, } \\
p<0.001 \text { ); daily intake } 46.5 \% \text { prevalence, } \\
\text { AOR }=3.05, p<0.001 .\end{array}$ \\
\hline $\begin{array}{l}\text { (Kozaric-Kovacic, Ljubin, \& Grappe, } \\
\text { 2000) } \\
\text { IDPs in Croatia }\end{array}$ & $\begin{array}{l}\text { Gender: Male }>\text { female }\left(\mathrm{Chi}^{2}=114.515,\right. \\
\mathrm{p}<0.001)\end{array}$ & $\begin{array}{l}\text { No. of trauma experiences: no association with } \\
\text { alcohol dependence. }\end{array}$ & $\begin{array}{l}\text { Alcohol dependence } \\
\text { more common in men } \\
\text { with PTSD }(69.6 \%) \\
\text { than without PTSD } \\
(51.3 \%) . \text { Chi } 2=4.783 \text {, } \\
p=0.029 \text {. This } \\
\text { association was not } \\
\text { significant in women. }\end{array}$ & $\mathrm{N} / \mathrm{A}$ \\
\hline $\begin{array}{l}\text { (Londono, Romero, \& Casas, 2012) } \\
\text { Young adults in Colombia }\end{array}$ & $\mathrm{N} / \mathrm{A}$ & $\begin{array}{l}\text { Alcohol abuse (undefined). Conflict vs non-conflict } \\
\text { exposure: among those exposed to } \\
\text { conflict }=54.54 \% \text {; among those with no exposure to } \\
\text { conflict }=21.42 \% \text {. OR }=4.4, p=0.05^{*}\end{array}$ & $\mathrm{~N} / \mathrm{A}$ & $\mathrm{N} / \mathrm{A}$ \\
\hline $\begin{array}{l}\text { (Luitel, Jordans, Murphy, Roberts, \& } \\
\text { McCambridge, 2013) Bhutanese } \\
\text { refugees in Nepal }\end{array}$ & $\begin{array}{l}\text { Gender: Male }>\text { female } A O R=2.81, p<0.001 . \\
\text { Educational status: Intermediate or above } \\
\text { AOR=0.35, } p<0.01 \text {. } \\
\text { History of alcohol use in family: } A O R=1.55 \\
p<0.05)\end{array}$ & $\mathrm{N} / \mathrm{A}$ & $\mathrm{N} / \mathrm{A}$ & $\begin{array}{l}\text { Hazardous drinking and substance misuse: } \\
\text { AOR }=10.77, p<0.001 \text {. } \\
\text { Hazardous drinking and tobacco use: } \\
\text { AOR }=2.10, p<0.01 \text {. } \\
\text { Religion: NS } \\
\text { Employment status: NS }\end{array}$ \\
\hline $\begin{array}{l}\text { (Maksimovic, Backovic, } \\
\text { Maksimovic, \& Kocijancic, 2011) } \\
\text { Adolescents in Belgrade, IDPs and } \\
\text { host }\end{array}$ & $\mathrm{N} / \mathrm{A}$ & $\begin{array}{l}\text { Alcohol consumption: no difference between IDPs } \\
\text { and host }(p=0.08)\end{array}$ & $\mathrm{N} / \mathrm{A}$ & $\mathrm{N} / \mathrm{A}$ \\
\hline (O'Donnell \& Roberts, 2015) & & $\begin{array}{l}\text { Alcohol use: refugee youth=15.2\%; Gambian } \\
\text { youth }=0.9 \%\left(C h i^{2}=47.54, p=0.001\right)\end{array}$ & & \\
\hline $\begin{array}{l}\text { Okello, Nakimuli-Mpungu, Musisi, } \\
\text { Broekaert, \& Derluyn, 2013) } \\
\text { Secondary school students in } \\
\text { northern Uganda } \\
\end{array}$ & Gender: NS OR=0.65, 95\% Cl 0.3-1.39 & $\mathrm{N} / \mathrm{A}$ & $\mathrm{N} / \mathrm{A}$ & $\mathrm{N} / \mathrm{A}$ \\
\hline $\begin{array}{l}\text { (Puertas, Rios, \& Valle, 2006) IDPs } \\
\text { in urban slums in Colombia }\end{array}$ & $\begin{array}{l}\text { Excessive alcohol consumption: } \\
\text { Men }=29.0 \%(95 \% \mathrm{Cl} 23.5 \%-34.5 \%) \text {; } \\
\text { women }=6.4 \%(95 \% \mathrm{Cl} 4.5 \%-8,6 \%)\end{array}$ & $\mathrm{N} / \mathrm{A}$ & $\begin{array}{l}\text { Excessive alcohol } \\
\text { consumption NS } \\
(P>0.05) \text { association } \\
\text { with common mental } \\
\text { disorders }\end{array}$ & $\mathrm{N} / \mathrm{A}$ \\
\hline
\end{tabular}




\begin{tabular}{|c|c|c|c|c|}
\hline $\begin{array}{l}\text { Roberts, Felix Ocaka, Browne, } \\
\text { Oyok, \& Sondorp, 2011) IDPs in } \\
\text { northern Uganda }\end{array}$ & $\begin{array}{l}\text { Association with alcohol disorders: } \\
\text { Gender:male }>\text { female } A O R=7.21, p=<0.001 \\
\text { Age (compared to }<29 \text { y.0.): } \\
30-39 \text { y.o. }(O R=2.32, p<0.001) ; 40-49 \text { y.o. } \\
\text { OR=2.94, } p<0.001 ; 50+y .0 . O R=4.14 \\
p<0.001 .\end{array}$ & $\begin{array}{l}\text { Association with alcohol disorders: } \\
\text { Cumulative trauma exposure: } 4-7 \text { events } \\
\text { AOR }=1.98, p=0.05 ; 8-11 \text { events } A O R=2 p=0.05 ; \\
12-16 \text { events } A O R=2.11, p=0.04) . \\
\text { Trauma types: imprisonment } O R=2.19, p=<0.00 ; \\
\text { brainwashing } O R=1.36, p=0.05 ; \text { isolation } O R=1.88 \text {, } \\
p<0.001 ; \text { escaped death } O R=1.63, p<0.01 ; \\
\text { separation } O R=1.71, p<0.001 ; \text { abducted } O R=1.68, \\
p<0.001 ; \text { beaten/tortured } O R=1.97 p<0.001)\end{array}$ & $\begin{array}{l}\text { PTSD and depression } \\
\text { with alcohol disorders: } \\
\text { NS }\end{array}$ & $\mathrm{N} / \mathrm{A}$ \\
\hline $\begin{array}{l}\text { Roberts, Murphy, Chikovani, } \\
\text { Makhashvili, Patel, \& McKee, 2014) } \\
\text { IDPs in Georgia }\end{array}$ & $\begin{array}{l}\text { Gender: Higher proportion of drinking in } \\
\text { men than women for frequency of drinking, } \\
\text { volume of alcohol consumed, and alcohol } \\
\text { use disorder (all } p<0.05) \text {. } \\
\text { Age for episodic heavy drinking (reference } \\
\text { category of }<29 \text { y.o); } 30-39 \text { y.o AOR=2.6, } \\
p=0.01 \text { ); } 40-49 \text { y.o. AOR=2.34, } p=0.02 \text { ) }\end{array}$ & $\begin{array}{l}\text { Association with hazardous drinking } \\
\text { Type of trauma experience: serious injury } \mathrm{OR}=2.36 \\
\mathrm{p}<0.001 \text {. } \\
\text { Cumulative trauma exposure: } 2 \text { events } \mathrm{AOR}=2.63 \text {, } \\
\mathrm{p}=0.02 ; 3 \text { events } \mathrm{AOR}=2.67, \mathrm{p}=0.04^{*} ; 4+\text { events } \\
\mathrm{AOR}=2.73,=0.01)^{* *}\end{array}$ & $\begin{array}{l}\text { PTSD and hazardous } \\
\text { drinking: NS } \\
\text { Depression and } \\
\text { hazardous drinking: } \\
\text { AOR }=2.65, p=0.01 .\end{array}$ & $\begin{array}{l}\text { Community level factors: } \\
1 \text { unit increase in alcohol environment factor } \\
\text { associated with increase in episodic heavy } \\
\text { drinking among men with (AOR1.27, p=0.04) } \\
\text { Harmful alcohol use and tobacco use: NS }\end{array}$ \\
\hline $\begin{array}{l}\text { (Saile, Neuner, Ertl, \& Catani, 2013) } \\
\text { Couples in northern Uganda }\end{array}$ & $\mathrm{N} / \mathrm{A}$ & $\mathrm{N} / \mathrm{A}$ & $\mathrm{N} / \mathrm{A}$ & $\begin{array}{l}\text { Association of male harmful alcohol use with } \\
\text { psychological partner violence }(p=0.02) \text { and } \\
\text { physical partner violence }(p=0.01) \text { experienced } \\
\text { by female partner, but not significantly } \\
\text { associated with isolation and sexual abuse. }\end{array}$ \\
\hline $\begin{array}{l}\text { (Saile, Ertl, Neuner, \& Catani, 2014) } \\
\text { Families in northern Uganda }\end{array}$ & N/A & N/A & $\mathrm{N} / \mathrm{A}$ & $\begin{array}{l}\text { Alcohol related problems in male guardian } \\
\text { associated with aggressive guardian-child } \\
\text { parenting behaviours }(p=0.03) \text {, but not } \\
\text { associated with child-reported victimisation in } \\
\text { family. }\end{array}$ \\
\hline $\begin{array}{l}\text { (Sibai, Tohme, Beydoun, Kanaan, \& } \\
\text { Sibai, 2009) Adolescents in Beirut, } \\
\text { Lebanon }\end{array}$ & $\mathrm{N} / \mathrm{A}$ & $\mathrm{N} / \mathrm{A}$ & $\mathrm{N} / \mathrm{A}$ & $\begin{array}{l}\text { Risk factors for physical fight: riding with a } \\
\text { drunk driver }(A O R=2.60, p<0.05) \text {; current } \\
\text { alcohol use }(A O R=1.78, p<0.05) ; \text { binge drinking } \\
\text { (AOR=4.18, } p<0.05) \text {; but driving after drinking } \\
\text { was NS. } \\
\text { Risk factors for weapon carrying: riding with a } \\
\text { drunk driver }(A O R=2.77, p<0.05) \text {; driving after } \\
\text { drinking }(A O R=2.92, p<0.05) ; \text { current alcohol } \\
\text { use }(A O R=1.80, p<0.05) \text {; binge drinking } \\
(A O R=3.99,8.92, p<0.05) \text {. }\end{array}$ \\
\hline
\end{tabular}


Table 3: Synthesis of risk-factors associated with harmful alcohol use

\begin{tabular}{|c|c|}
\hline RISK-FACTORS & (Article) \\
\hline \multicolumn{2}{|l|}{ Demographic factors: } \\
\hline Gender (men compared to women) & $\begin{array}{l}\text { (Abu Qamar, Thabet, \& Vostanis, 2007) } \\
\text { (Ezard, Thiptharakun, Nosten, Rhodes, \& McGready, 2012) } \\
\text { (Harris, Levey, Borba, Gray, Carney, \& Henderson, 2012) } \\
\text { (Jovic-Vranes, Vranes, Marinkovic, \& Cucic, 2005) } \\
\text { (Kozaric-Kovacic, Ljubin, \& Grappe, 2000) } \\
\text { (Luitel, Jordans, Murphy, Roberts, \& McCambridge, 2013) } \\
\text { (Puertas, Rios, \& Valle, 2006) } \\
\text { (Roberts, Felix Ocaka, Browne, Oyok, \& Sondorp, 2011) } \\
\text { (Roberts, Murphy, Chikovani, Makhashvili, Patel, \& McKee, 2014) } \\
\text { NS (Okello, Nakimuli-Mpungu, Musisi, Broekaert, \& Derluyn, 2013) }\end{array}$ \\
\hline Older age & $\begin{array}{l}\text { (Ezard, Thiptharakun, Nosten, Rhodes, \& McGready, 2012) } \\
\text { (Harris, Levey, Borba, Gray, Carney, \& Henderson, 2012) } \\
\text { (Roberts, Felix Ocaka, Browne, Oyok, \& Sondorp, 2011) } \\
\text { (Roberts, Murphy, Chikovani, Makhashvili, Patel, \& McKee, 2014) } \\
\text { NS (Fu \& Van Landingham, 2010) }\end{array}$ \\
\hline Marital status (being single) & (Abu Qamar, Thabet, \& Vostanis, 2007) \\
\hline Lower education level & $\begin{array}{l}\text { (Luitel, Jordans, Murphy, Roberts, \& McCambridge, 2013) } \\
\text { NS (Fu \& Van Landingham, 2010) }\end{array}$ \\
\hline \multicolumn{2}{|l|}{ Conflict and trauma exposure: } \\
\hline Cumulative trauma exposure & $\begin{array}{l}\text { (Londono, Romero, \& Casas, 2012) } \\
\text { (Roberts, Felix Ocaka, Browne, Oyok, \& Sondorp, 2011) } \\
\text { (Roberts, Murphy, Chikovani, Makhashvili, Patel, \& McKee, 2014) } \\
\text { NS (Kozaric-Kovacic, Ljubin, \& Grappe, 2000) }\end{array}$ \\
\hline Conflict and forced displacement & $\begin{array}{l}\text { (Bosnar, Stemberga, Cuculic, Zamolo, Stifter, \& Coklo, 2004) } \\
\text { (O'Donnell \& Roberts, 2015) } \\
\text { NS (Maksimovic, Backovic, Maksimovic, \& Kocijancic, 2011) }\end{array}$ \\
\hline \multicolumn{2}{|l|}{ Mental disorders: } \\
\hline PTSD & $\begin{array}{l}\text { (Kozaric-Kovacic, Ljubin, \& Grappe, 2000) } \\
\text { NS (Roberts, Felix Ocaka, Browne, Oyok, \& Sondorp, 2011) } \\
\text { (Roberts, Murphy, Chikovani, Makhashvili, Patel, \& McKee, 2014) }\end{array}$ \\
\hline Depression & $\begin{array}{l}\text { (Roberts, Murphy, Chikovani, Makhashvili, Patel, \& McKee, 2014) } \\
\text { NS (Puertas, Rios, \& Valle, 2006) }\end{array}$ \\
\hline \multicolumn{2}{|l|}{ Other factors: } \\
\hline Family history of alcohol use & (Luitel, Jordans, Murphy, Roberts, \& McCambridge, 2013) \\
\hline $\begin{array}{l}\text { Community influences (alcohol } \\
\text { marketing, availability, price) }\end{array}$ & (Roberts, Murphy, Chikovani, Makhashvili, Patel, \& McKee, 2014) \\
\hline Experiencing bullying at school & (Jovic-Vranes, Vranes, Marinkovic, \& Cucic, 2005) \\
\hline \multicolumn{2}{|c|}{$\begin{array}{l}\text { Notes: NS = non-significant }(P>0.05) \text { associations between risk-factor and harmful alcohol use } \\
\text { Citations in italics reported non-significant }(P>0.05) \text { associations between risk-factors and harmful alcohol use. } \\
\text { Citations in bold are those graded as strong quality (see Online Annex } 4 \text { for detailed quality assessment results). }\end{array}$} \\
\hline
\end{tabular}

